\title{
Is cultural logic an appropriate concept? A semiotic perspective on the study of culture and logic
}

\author{
Sadeq Rahimi \\ Culture and Mental Health Research Unit; ICFP-Jewish General Hospital \\ 4333 Cote Ste. Catherine, Montreal, Quebec, H3T 1E4 Canada \\ e-mail: srahimi@med.mcgill.ca
}

\begin{abstract}
It is argued that (a) the question of 'cultural logic' is a valid inquiry for disciplines seeking to comprehend and compare mental processes across cultures, and (b) semiotics, as the science of studying signs and signification, is an appropriate means of approaching the question of cultural logic. It is suggested that a shift needs to be made in studying reasoning across cultures from the traditional value-oriented methods of judgment to a meaningoriented assessment. Traditional methods of cross-cultural comparison are suggested to be flawed in their attempt to develop a psychological account of why different cultural societies can draw different conclusions from 'similar' data, because they typically do not take into account the culturally-specific processes of 'meaning' and semiosis. These processes, it is argued, cause input data to develop differentially from one semiotic context to another. In other words, before reaching the cognitive processing level data is already shaped by the semiotic context, thus what is processed cognitively by two individuals in two cultural/semiotic contexts is no longer 'the same.' A semiotically conceived notion of cultural logic is therefore a crucial factor in any cross-cultural study of cognitive and psychological systems.
\end{abstract}

I do not, for my part, regard the usages of language as forming a satisfactory basis for logical doctrine. Logic, for me, is the study of the essential conditions to which signs must conform in order to function as such. How the constitution of the human mind may compel men to think is not the question; and the appeal to language appears to me to be no better than an unsatisfactory method of ascertaining psychological facts that are of no relevancy to logic.

C. S. Peirce ${ }^{1}$

${ }^{1}$ Quoted in Parmentier 1994: 12. 
Reasoning is a process that occurs within linguistic, social, and cultural environments, and involves the employment of universal and/ or culturally specific meanings; and logic, or the process of "establishing necessary connections between these meanings", as Levi Strauss (1966: 35) once put it, is always defined by and bound within these linguistic, social, and cultural parameters.

If we consider reasoning as the fundamental element of logical processing, and if we agree that this fundamental element is conceived within and wrought by language and culture, then we can argue:

First, that the question of 'cultural logic' is a valid inquiry for disciplines such as cultural psychiatry, which seek to comprehend and to compare mental processes across cultures, and secondly, that semiotics, as the science of studying signs and signification, is an appropriate means of approaching the question of cultural logic.

In the following paper, I will argue that 'cultural logic' is an appropriate term, and that the notion of cultural logic establishes a legitimate question for cross cultural studies of psychological, cognitive and behavioral phenomena. Further, I will argue that semiotic analysis provides an advantageous method for sketching the shape of the 'logic' of a given culture.

Let me begin my discussions with an example of what I have in mind when I discuss cultural logic. This is an excerpt from an interview designed by a Western psychologist, American Michael Cole. The respondent is a Kpelle tribal leader, from Liberia, Africa (Cole, Scribner 1974: 162).

Interviewer: At one time spider went to feast. He was told to answer this question before he could eat any of the food. The question is: spider and black deer always eat together. Spider is eating. Is black deer eating?

Elder: Were they in the bush?

I: Yes.

$E$ : Were they eating together?

I: Spider and black deer always eat together. Spider is eating. Is black deer eating?

$E$ : But I was not there. How can I answer such a question?

I: Can't you answer it? Even if you weren't there, you can answer it. (Repeats the question.)

$E$ : Oh, oh, black deer is eating.

I: Why?

$E$ : The reason is that black deer always walks about all day eating leaves in the bush. Then he rests for a while and gets up again to eat. 
When Cole himself explains this interview, he says the elder, though involved in an active process of reasoning, is struggling "to find a factual basis for arriving at a conclusion", and he points out as evidence the elder's demands for facts like whether the animals were in the bush at that time, or if they were eating together. To be sure, Cole is not one to go to such lengths as did some of his predecessors like Levy-Bruhl. In his book titled How Natives Think (which stands as a polite translation for "Les Fonctions Mentales dans les Sociétés Inférieures"), Lucien Levy-Bruhl (1926) proposed the idea of two basic developmental levels of logic: the pre-logical, as manifested by the "native mind", and then the logical, as manifested by the "adult white man". I will not get into details of this division here, but in looking at Cole's effort fifty years after Les Sociétés Inférieures to explain the method the Kpelle elder uses to infer his conclusion, it is hard to ignore the traces of Levy-Bruhl's, or specially Luria's ${ }^{2}$ legacies. What Luria did to Levy-Bruhl's crude colonial grouping was to tone it down to a softer version. According to Luria's vision the world is divided between those whose reasoning process is bound within the concrete, immediate life experiences; and those who are capable of abstract conceptualization and reasoning within those abstract spaces. Needless to say, it so happens that the first group, the 'concrete thinkers', generally live in rural areas, while the second reside in 'modern' urban settings. This historical glance already puts a context around the example from Cole's work.

Of the people just mentioned here, Cole appears to be the gentlest of all, when it comes to drawing conclusions from differences between the West and the rest. This is specially more evident in his other works, like his comparing the reasoning styles of American college students and Kpelle subjects around a story about two men who go to find themselves wives, and the approaches they choose in convincing the girl's father". We don't afford the luxury of details here, but let me quote what he says about the results of his comparative study. "The most interesting result of this study," he says, was that "the American college students and all the Kpelle groups had the same percentage of wrong answers - there were no group differences in errors. But the American college students exceeded all three Kpelle groups in the percentage of correct answers". (The word 'correct' is actually

${ }^{2}$ See for example Luria (1971). Luria studied reasoning and cognitive styles of traditional societies in rural Russia, with Vygotsky in the 1960s.

${ }^{3}$ See Cole, Scribner 1974 for details. 
emphasized in the original text). Cole then continues to explain that, "this seeming paradox is accounted for by the fact that fully one-fifth of the Kpelle replies [...] was irrelevant" (Cole, Scribner 1974: 167). To be fair, it is important to note that he does not rush to attribute this difference to some kind of deficiency of the Kpelles' pre-logical mind. Yet what he does is still significant, on two counts: first, his interpretation of the Kpelle elder's search for more information falls back on Luria's division of the concrete and the abstract styles rather than a more critical inquiry of either the process or the content of his interviews, and secondly, he appears fully oblivious of the questions of meaning and relevance when he simply reports a full one-fifth of the Kpelle replies were deemed 'irrelevant'. The absence of a critical, or even a non-critical evaluation of the notion of 'irrelevance' in Cole's text is quite striking, making it inevitable to ask the question of validity, specifically based on a semiotic inspection of the case.

Cole's interviews are effectively conglomerate signs, and any basic examination of them should consider at least two levels of analysis: the interview process and design as form (the setting, the presentation, the individuals involved, etc.); and the interview question and its components as content. Considered in terms of the form, the interview is a sign with complex culturally specified referents. The encounter in a North American college with an interviewer, typically in a lab or similar space, and being told 'you are going to be asked a question by an interviewer' signify a social action with pre-scribed meanings different from those in the encounter between Cole and the Kpelle elder. If the American treat the situation in abstraction, that is perhaps because innumerable form signs communicated prior to the actual content all have been packed historically, linguistically, socially, and culturally, to be decoded by the subject as: 'this is a situation where you are given a question and you are demanded to process that question in abstract terms and produce an abstract response to it'. The same message is not necessarily communicated to the Kpelle subject, however, when he is met by an interviewer who asks him to listen to the story of black deer who goes to feast with spider and answer a question about that story. The actual question as content, and the type of response elicited by it embody yet another culturally specific sign with culturally specific reference. For one thing, the understanding of the 'type' of question being asked has great bearing on the 'type' of response the person would provide (hence the critical importance of 'misleading' as a control measure in cognitive testing). If a question signifies an ethical inquiry, for example, the elicited response can be 
quite different than if the same question stood for a political or a philosophical query. Further, the question-sign is composed of a series of signs including (and not limited to) spider, deer, a feast, going to a feast, going to a feast together, eating together, being in the bush, and so on. These multitudes of signs all have culturally specific meanings. It is not difficult to entertain the idea for example, that while the story of a spider who goes to feast together with the black deer may suggest a serious meaningful situation to the Kpelle respondent, to the American college student it is likely to signify little more than an abstract element within an abstract (though peculiar, perhaps) set presenting a standard syllogistic question. Consequently, while in the American mainstream version of reality it would be 'bizarre' to think of a spider going to feast together with a black deer in any terms other than abstract, in the Kpelle frame of reference there may be no need for such urgent abstraction. Whereas Cole's spider-and-deer question may be read immediately by the North American subject as a 'sign of' an abstract inquiry demanding an abstract response, there is no reason why it should signify the same to a Kpelle subject. If the elements of a question evoke different semiotic configurations to two persons, in other words, it should be hardly surprising to see them proceed differently with their responses to that question.

In addition to the obvious colonial arrogance, and the Eurocentric naivety inherent in the theories constructed by Bruhl or even by Cole, a fundamental technical problem with these methods of analysis is that they attempt to explain cultural processes in terms of intellectual and psychological faculties. This creates a critical problem, whether they start from the culture and end in the individual's psychology, as does Cole (e.g., 1971, 1974), or start from the psyche to define cultural complexes, as Levy-Bruhl seems to do. What is important is that a shift needs to be made in studying reasoning across cultures: a shift from the traditional value oriented methods of judgment to a meaning oriented assessment. The new discipline of cognitive anthropology seems also to slip when threading this slope, despite the more recent developments which tend to approach the question of meaning in their inquiries on culture and logic. The more recent literature contain notions borrowed from cognitive psychology such as scripts and cultural schemata (see D'Andrade 1995 for a review), as well as works in the tradition of Lakoff (e.g., Lakoff, Johnson 1980, or Lakoff, Turner 1989) which center around metaphoric thinking. Even though a more serious attention to cognition and meaning is evident in these new approaches, much of these inquiries don't seem to break 
free from the old paradigm of searching similarities or differences between logical systems based simply on the hypothesis that different styles of mental functioning may lie behind such logical systems.

What lies at the core of my argument here is that any research designed to develop a psychological account of why different cultural societies can draw different conclusions from 'similar' data is already flawed. It is flawed because data, by the time it reaches the reasoning process level in each context, is already translated differently by having gone through different semiotic and semantic 'filters'. If we agree on this simple fact that the signification of any input is inevitably decided by the semiotic environment it is thrown in, it would then be clearly incorrect to assume that two subjects belonging in two different semiotic networks are processing similar data just because the stories they are told by the experimenter have been translated into their respective mother tongues.

James Hamill is another anthropologist who dedicated work to culture and logic more recently. In his anthropology of human reasoning, Hamill (1990) suggests that while philosophical logic, or textbook logic as he calls it, is abstract and does not refer to any specific human activity, it might be useful in providing a scale against which various culturally specific systems of reasoning can be compared, and universal and non universal styles of reasoning can be identified. While Hammill's approach may provide a useful model for comparative logics, what does not seem to be clarified in it is the fate of such diverse 'cultural logics' themselves. True, using a system of comparison may give us a scale to distinguish cultural logics according to their systems of reasoning. Such classificatory system, however, would not be able to explain how these differences have come to exist.

Hamill comes a long way from Cole and his predecessors. He admits that validity of arguments in a culture specific system of reasoning has to be judged within the context of the "patterns of meaning that people use to make their cases" (Hamill 1990: 19). He is quick of course, to point out that using meaning to contextualize arguments may in fact not be as simple a task, and that we therefore require "some principled means of reaching the meanings that stand behind what [we] see" (Hamill 1990: 19). Intriguingly enough, however, instead of going the remaining small step from this to calling on semiotics, he proposes that "the study of errors or mistakes provides that means" (Hamill 1990: 19). I have followed Hamill's line of discussion closely, because I tend to share much of it with him, almost all the way to the last point, on the utility of errors for depicting cultu- 
ral logic, or as he calls it, ethno-logic. Using errors is an interesting idea of course, one which brings to mind on the one hand Freud's notion of parapraxes, ${ }^{4}$ and on the other Eco's description of semiotics as "the discipline studying everything which can be used in order to lie" (Eco 1976: 7). But despite the attractiveness of an error based analysis of meaning, we clearly need a more comprehensive and reliable system of analysis. While errors might cause a 'rip', so to speak, in the discursive fabric and give us a glimpse of the network that binds the system of reasoning together, such accidental sparks can hardly substantiate a reliable or efficient method of analysis. What I would like to suggest at this point is that a methodical inquiry into the system of signification can give us that 'principled method of reaching the meanings' we discussed earlier. Semiotic analysis, in other words, may be the most appropriate means available for unearthing the patterns of meaning that engender a certain cultural logic.

So far I have argued that the advantage of a notion such as cultural logic is in that it allows for the validity of arguments produced by the subject to be decided in the context of the systems of meaning (in terms both of production and connectivity of these meanings) used to process those arguments. This was suggested to be an advantageous model, because in the context of studying cultures, specially as related to mental health, occasionally we arrive at a point where Western propositional logic seems to fail us, leaving us to select between the anxiety of confusion, or the naivety of a Eurocentric interpretation of the 'native' mind as illogical, inferior, or flawed. The notion of cultural logic extends our options by making it possible to include a sense of dimensionality in our configuration of what constitutes a valid process of reasoning. This inclusion is done by the admittance that patterns of production of meaning and the structures of connectivity between those produced meanings have a formative presence in what we normally refer to as the process of reasoning, or its product, logic. Needless to say, this is the point where the question of signification, or semiotics, becomes pertinent to this discussion.

To put this in another perspective, consider the fact that three main inquiries are conceivable for a semiotic examination of culture: The first would interrogate the act of signification, the process through which an object becomes a sign and thus endowed by the capacity of signifying another object; the second would study the act of representation, or the process through which a sign/object becomes linked

\footnotetext{
${ }^{4}$ See, for example, Freud 1914.
} 
to a referent/object; and finally the third inquiry would concern the inter-connectivity of the sign/objects within the system that represents those objects, and the production of the network to which we often refer as the system of signification.

The third question of this set, that of the system of signification, is a crucial question for a semiotics of culture. Culture has been described as an instance of a 'system of signification,' with the distinctive feature of being composed not simply of information, but also of formulations for processing and then connecting the components of that information (see, for example, Danesi 1999). As such, any inquiry of the nature of cultural logic must take into account not simply the pre existing network of meaning or the informational content of a cultural system, but also the auxiliary information that contains blueprints for processing and connecting new data and incorporating it within the existing nexus. This aspect is in fact where cognitive anthropology seems to become interested, when it asks the question of schemata. A semiotic approach would seem appropriate in studying this so called auxiliary information, since like any other communicated data, this information has to be communicated within the temporal, notational, and structural or operational parameters of dimensionality (see Danesi 1998, 1999). Of these three dimensions, the notational dimension pertaining to the connotative, the denotative and the annotative aspects of a sign, is perhaps the one with a greater contribution to cross cultural variability of 'logics', because it relates directly to the process of ascribing meaning to new input and situating it as signifier within the pre existing network. Deciphering this assimilative process would be vital to understanding the dynamics of a culture's brand of logic, specially since it is done in a more or less 'invisible' fashion, not necessarily reflected in the linguistic structure in an evident manner. Neither a syntactical, nor even a standard semantic analysis would necessarily depict this process of integration, because neither of these approaches. So while the instrumental role of language in this inquiry may not be denied, traditional linguistic methods of linguistic analysis appear inadequate, due to their inability in unpacking the semiotic content. Semiotic analysis, in other words, may be the most appropriate means available for unearthing the patterns of connectivity specific to a culture.

It seems only appropriate at this point to conclude my arguments by once again repeating Peirce's assertion, that logic concerns "The essential conditions to which signs must conform in order to function as such. How the constitution of the human mind may compel men to 
think is not the question; and the appeal to language appears to me to be no better than an unsatisfactory method of ascertaining psychological facts that are of no relevancy to logic". 5

\section{References}

Cole, Michael; Gay, John; Glick, Joseph A.; Sharp, Donald W. 1971. The Cultural Context of Learning and Thinking. New York: Basic Books.

Cole, Michael; Scribner, Sylvia 1974. Culture and Thought: A Psychological Introduction. New York: Wiley.

D'Andrade, Roy 1995. The Development of Cognitive Anthropology. New York: Cambridge University.

Danesi, Marcel 1998. Sign, Thought, and Culture: A Basic Course in Semiotics. Toronto: Canadian Scholars' Press.

Danesi, Marcel; Perron, Paul 1999. Analyzing Culture: An Introduction and Handbook. Bloomington: Indiana University Press.

Eco, Umberto 1976. A Theory of Semiotics. Bloomington: Indiana University Press.

Freud, Sigmund 1914. Psychopathology of Everyday Life. London: T. Fisher Unwin.

Hamill, James Francis 1990. Ethno-Logic: The Anthropology of Human Reasoning. Urbana: University of Illinois Press.

Lakoff, George; Johnson, Mark L. 1980. Metaphors We Live By. Chicago: Chicago University Press.

Lakoff, George; Turner, Mark 1989. More than Cool Reason: A Field Guide to Poetic Metaphor. Chicago: Chicago University Press.

Levy-Bruhl, Lucien 1926. How Natives Think. Translated by Lilian A. Clare. London: G. Allen and Unwin.

Lévi-Strauss, Claude 1966. The Savage Mind. Chicago: University of Chicago Press.

Luria, Aleksandr R. 1971. Towards the problem of the historical nature of psychological processes. International Journal of Sociology 31: 544-558.

Parmentier, Richard 1994. Signs in Society: Studies in Semiotic Anthropology. Bloomington: Indiana University Press.

\section{Является ли логика культуры подходящим концептом? Семиотический подход к изучению культуры и логики}

В статье утверждается, что (а) рассмотрение «логики культуры» полезно в дисциплинах, которые ишут возможности для понимания и сравнения разных культур, и (б) семиотика как наука о знаках и значениях является подходящим инструментом при подходе к вопросу о логике культуры.

${ }^{5}$ Quoted in Parmentier 1994: 12. 
При изучении традиции мышления в разных культурах следует заменить традиционные ценностно-ориентированные методы решений созданием оценок, ориентированных на значение. Пытаясь развивать психологическое объяснение того факта, что разные культурные сообщества приходят к разным выводам при «похожих» исходных данных, автор обнаруживает, что традиционные методы сравнения культур являются некорректными, - зачастую не учитываются культурноспецифические процессы «значения» и семиозиса. Показывается, что эти процессы предопределяют разную интерпретацию входных данных при переходе из одного семиотического контекста в другой. Иными словами, еще до достижения уровня когнитивной обработки эти данные уже сформированы семиотическим контекстом, поэтому то, что когнитивно обрабатывалось двумя разными личностями в двух разных культурно-семиотических контекстах, уже не является «одним и тем же». Таким образом, семиотически оформленное понимание логики является решающим фактором при любом кросс-культурном изучении всех когнитивных и психологических систем.

\section{Kas kultuuriloogika on asjakohane mõiste? Semiootiline lähenemine kultuuri ja loogika uurimisele}

Artiklis väidetakse, et (a) "kultuuriloogika" vaatlemine on küsimusepüstitusena sobiv distsipliinide osas, mis otsivad võimalusi erinevate kultuuride ja nendevaheliste mentaalsete protsesside mõistmiseks ja võrdlemiseks, ning (b) semiootika kui märkide ja tähenduse uurimise teadus on sobivaks vahendiks kultuuriloogika küsimusele lähenemisel. Kultuuridevahelise mõtlemise traditsiooni uurimisel soovitatakse nihkuda väärtus-orienteeritud otsuste tegemiselt tähendusele orienteeritud hinnangute andmisele. Oma katsetes arendada psühholoogilist seletust, põhjendamaks, miks erinevad kultuurisootsiumid jõuavad erinevate järeldusteni "sarnaste" lähteandmete põhjal, arvatakse traditsioonilised meetodid kultuuride võrdlemiseks olevat ebakorrektsed - tüüpiliselt ei võeta arvesse "tähenduse" ja semioosi kultuurispetsiifilisi protsesse. Näidatakse, et need protsessid põhjustavad sisendandmete erinevat tõlgendamist üleminekul ühest semiootilisest kontekstist teise. Teisisõnu, enne kognitiivse töötluse tasemele jõudmist on andmeid juba vormitud semiootilise konteksti poolt, seega see, mis on kahe isiku poolt kognitiivselt töödeldud kahes erinevas kultuurilises/semiootilises kontekstis ei ole enam "sama". Semiootiliselt kujundatud arusaam kultuuriloogikast on seetõttu otsustavaks faktoriks kõigi kognitiivsete ja psühholoogiliste süsteemide kultuuridevahelises uurimises. 